\title{
Gastroesophageal reflux disease in infants who presented Brief Resolved Unexplained Event (BRUE)
}

\author{
Maria Angela BELLOMO-BRANDÃ ${ }^{1,2}$, Fernanda Maso STRANGUETTI', lara Ferreira LOPES ${ }^{1}$, \\ Andressa Oliveira PEIXOTO ${ }^{1,2,3}$, Fernando Augusto Lima MARSON ${ }^{1,2,3,4,5}$ and Elizete Aparecida LOMAZI ${ }^{1}$
}

Received: 11 December 2020 Accepted: 15 June 2021

\begin{abstract}
Background - The term brief resolved unexplained events (BRUE) is a description of the acute event occurring in infants less than 1-year-old that includes at least one of the following characteristics: cyanosis or pallor; absent, decreased, or irregular breathing; marked change in tone or altered level of responsiveness. An investigative proceeding is required to identify the triggering phenomenon in those who are at high risk of complications. Prolonged esophageal pHmetry has been used as a tool in searching for gastroesophageal reflux disease (GERD) as one of the underlying etiologies. Objective - The study aims to verify the frequency of GERD in infants up to 1-year-old, when pHmetry has been performed for investigating highrisk BRUE (HR-BRUE) and to analyze if clinical characteristics or any particular symptom related by caregivers during BRUE could be correlated to GERD. Methods - It was performed a cross-sectional study. The data was collected retrospectively of patients less than 1-year-old, who had performed pHmetry in a tertiary hospital for investigating HR-BRUE between October 2008 and January 2018. For the analysis of medical records, a data collection protocol included: gender, age at the first HR-BRUE episode, age at the time of the pHmetry, gestational age, type of delivery (normal or caesarean) and birth weight and symptoms associated to HR-BRUE related by caregivers. Relation between variables were assessed using Fisher's exact test and Mann-Whitney test. The significance level was set at 0.05. Results - A total of 54 infants were included (preterm 25, term 29), 62.9\% males, median age at the HR-BRUE was 36 days, 53.7\% HR-BRUE episodes had occurred during or right after feeding. According to pHmetry results: nine pHmetry results were considered inconclusive, physiological reflux $(n=30)$ and GERD $(n=15)$. The frequency of GERD diagnosed by pHmetry was $33 \%$. GERD was not statistically related to gender $(P$-value $=0.757)$, age at first HR-BRUE episode $(P$-value $=0.960)$, age at the time of the pHmetry $(P$-value $=0.720)$, prematurity $(P$-value $=0.120)$ or type of delivery $(P$-value $=0.738)$. GERD was statistically related to low birth weight $(P$-value $=0.023)$. There was no association between symptoms reported by caregivers during HR-BRUE and GERD. Conclusion - GERD diagnosed by the pHmetry was found in one third of infants that experiencing a HR-BRUE, showing the importance of properly investigation. In half of infants BRUE occurred during or right after feeding. Besides low birth weight, it was not possible to select other data from the clinical history that suggest that these patients would be more likely to have GERD.
\end{abstract}

Keywords - Brief resolved unexplained events; apparent life-threatening events; gastroesophageal reflux disease; infants; neonates.

\section{INTRODUCTION}

Initially, infants who were evaluated after a sudden and apparently fatal event were classified as having sudden infant death syndrome (SIDS), subsequently, as apparent life-threatening event (ALTE), defined as an alarming episode characterized as a combination of apnea; color change, usually cyanotic or pallid; marked change in muscle tone (usually marked limpness); choking or gagging $^{(1)}$. In 2016, the American Academy of Pediatrics introduced the term brief resolved unexplained events (BRUE) aiming to facilitate diagnosis and to reduce the episode's impact on caregivers. The definition of BRUE includes at least one of the following characteristics: cyanosis or pallor; absent, decreased, or irregular breathing, marked change in tone (hypertonia or hypotonia); or altered level of responsiveness, occurring in infants under 1-yearold. During BRUE, caregivers report a sudden, brief episode (less than one minute) but then resolved. Infants with BRUE have been categorized as low-risk patients, who require brief monitoring, or as high-risk patients, who need further investigation and treatment $t^{(2-5)}$, including investigation of gastroesophageal reflux disease $(\text { GERD })^{(6)}$. Physical examination and a detailed clinical history are essential in determining the possible causes of BRUE, including child abuse, arrhythmias and others cardiac conditions, metabolic diseases, and other factors.

Gastroesophageal reflux consists in the involuntary passage of gastric content into the esophagus, with or without externalization by mouth in the form of regurgitation and/or vomiting, it is a physiological event that occurs in all individuals - especially

1 Universidade Estadual de Campinas, Faculdade de Ciências Médicas, Departamento de Pediatria, Campinas, SP, Brasil. ${ }^{2}$ Universidade Estadual de Campinas, Faculdade de Ciências Médicas, Centro de Investigação em Pediatria, Campinas, SP, Brasil. ${ }^{3}$ Universidade Estadual de Campinas, Faculdade de Ciências Médicas, Hospital Universitário, Unidade de Pronto Atendimento de Urgência e Emergência, Campinas, SP, Brasil. ${ }^{4}$ Universidade Estadual de Campinas, Faculdade de Ciências Médicas, Departamento de Genética e Medicina Genômica, Campinas, SP, Brasil. ${ }^{5}$ Universidade São Francisco, Programa de Pós-Graduação em Ciências da Saúde, Bragança Paulista, SP, Brasil.

Corresponding author: Maria Angela Bellomo-Brandão. E-mail: angbell@unicamp.br 
infants. Some children may develop GERD, which occurs when reflux causes symptoms or complications ${ }^{(7-9)}$. According to North American Society for Pediatric Gastroenterology, Hepatology and Nutrition (NASPGHAN) and European Society for Pediatric Gastroenterology, Hepatology and Nutrition (ESPGHAN) guidelines, published in 2018, pH-metry and multichannel intraluminal impedance coupled to a $\mathrm{pH}$-meter sensor ( $\mathrm{pH}-\mathrm{MII})$ are both recommended methods for the diagnosis of GERD. Such guidelines consider anti-reflux surgery in infants with GERD and life-threatening complications such as apneas or BRUE ${ }^{(10)}$.

Although there are studies that have analyzed GERD and lifethreatening events relation ${ }^{(11-13)}$, the issue is still controversial, since reflux assessment methods vary widely. This study aims to verify the frequency of GERD in infants up to one-year-old, when pHmetry has been performed for investigating currently classified as highrisk BRUE (HR-BRUE). The secondary aim was to analyze if any particular symptom of HR-BRUE could be correlated to GERD.

\section{METHODS}

It was done a cross-sectional study and the clinical data was collected retrospectively of patients less than 1-year-old, who had performed pHmetry in a tertiary hospital for investigating HRBRUE or retrospective application of the HR-BRUE criteria, defined as: less than 60 days of life, or gestational age less than 32 weeks and corrected gestational age less than 45 weeks, or more than one event, or needed of resuscitation maneuvers ${ }^{(2)}$, between October 2008 and January 2018.

For the analysis of medical records, a data collection protocol included: gender, age at the first HR-BRUE episode, age at the time of the pHmetry, gestational age, type of delivery (normal or caesarean) and birth weight. Prematurity and low birth weight were defined by World Health Organization (WHO):

- prematurity ${ }^{(14)}$ : preterm $<37$ weeks of gestational age;

- low birth weight ${ }^{(15)}$ : weight at birth less than 2,500 g (5.5 lb).

Symptoms associated to HR-BRUE: HR-BRUE episode during or right after feeding, vomiting, choking, hypertonia, hypotonia, cyanosis, apnea, and pallor were presented as positive (presence) by the description in the medical records. In this context, the absence of information was considered as a negative result.

Exclusion criteria: patients diagnosed with genetic syndrome or malformations, or those not classified as HR-BRUE.

Prolonged esophageal pHmetry: the ALACER III ${ }^{\circledR}$ (Alacer biomédica Ltda.) portable recorder was used, connected to a singlechannel antimony electrode, calibrated prior to each examination using $\mathrm{pH}$ standard solutions of 7 and 1 . The electrode was introduced in one of the nostrils, positioned using the Strobel's formula [Height $(\mathrm{cm}) \times 0,252]$ and position was confirmed by X-ray ${ }^{(16)}$. No gastric acid suppressors (hydrogen potassium blocker or proton pump inhibitor) were used in the week prior to the examination. Routine diets and physical activities were maintained. In esophageal pHmetry, the diagnosis of GERD was made through the reflux index $(\mathrm{RI})$, defined as the percentage of time that $\mathrm{pH}<4$. Then, GERD was defined as $\mathrm{pH}<4$ for $>10 \%$ for infants $<1$ year and physiological reflux was established for all infants who did not reach a $10 \%$ RI; in the absence of BRUE episodes ${ }^{(16)}$.

The study was approved by the local Research Ethics Committee of the University - number \#92692718.0.0000.5404.

Relation between variables were assessed using Fisher's exact test and Mann-Whitney test. The significance level was set at 0.05.

\section{RESULTS}

The study included 54 infants with HR-BRUE, 34/54 males; 29 term; 25 preterm; 20 normal delivery, 34 caesarean delivery; 36 normal birth weight, 18 low birth weight. Clinical data are summarized in TABLE 1.

TABLE 1. Clinical characteristics of infants investigated by high-risk brief resolved unexplained events (HR-BRUE) $(n=54)$.

\begin{tabular}{|c|c|c|}
\hline Variables & Frequency & Percentage \\
\hline \multicolumn{3}{|l|}{ Gender } \\
\hline Male & 34 & $62.96 \%$ \\
\hline Female & 20 & $37.04 \%$ \\
\hline \multicolumn{3}{|l|}{ Type of delivery } \\
\hline Normal & 20 & $37.03 \%$ \\
\hline Caesareans & 34 & $62.29 \%$ \\
\hline \multicolumn{3}{|l|}{ Prematurity } \\
\hline Pre-term ${ }^{a}$ & 25 & $42.29 \%$ \\
\hline Term $^{a}$ & 29 & $53.71 \%$ \\
\hline \multicolumn{3}{|l|}{ Birth weight } \\
\hline Low weight ${ }^{\mathrm{b}}$ & 18 & $33.33 \%$ \\
\hline Normal weight ${ }^{\mathrm{b}}$ & 36 & $66.67 \%$ \\
\hline
\end{tabular}

${ }^{\mathrm{a} C l a s s i f i c a t i o n ~ o f ~ g e s t a t i o n a l ~ a g e: ~ t e r m ~} \geq 37$ weeks; preterm $<37$ weeks; ${ }^{\mathrm{b}}$ Classification of birth weight: less than 2,500 $\mathrm{g}$ - low weight; above 2,500 $\mathrm{g}$ - normal weight.

First HR-BRUE episode occurred at mean of $42.98 \pm 40.82$ days, median age of 36 days, ranging from 1 to 180 days of life. Regarding age at the time of the $\mathrm{pHmetry}$, mean: $76.67 \pm 49.65$ days was identified, with a minimum of 13 days, a median of 65 days and a maximum of 222 days.

Results of frequency of symptoms associated to HR-BRUE were showed in in TABLE 2; 29/54 (53.7\%) HR-BRUE episodes were reported as having occurred during or right after feeding.

Nine pHmetry results were considered inconclusive by lack/ poor information about posture/feeding or detachment of the external pHmetry sensor with consequent insufficient analysis time. Such exams were not repeated, as other etiologies had been identified. No BRUE episodes occurred during pHmetry monitoring.

TABLE 2. Distribution of frequency and percentage of symptoms recorded in medical file as related to the high-risk brief resolved unexplained events (HR-BRUE).

\begin{tabular}{lcc}
\hline Symptom & Frequency & Percentage \\
\hline Episode during or right after feeding & 29 & $53.7 \%$ \\
Vomiting & 19 & $35.19 \%$ \\
Choking & 12 & $22.22 \%$ \\
Hypertonia & 5 & $9.26 \%$ \\
Hypotonia & 18 & $33.33 \%$ \\
Cyanosis & 45 & $83.33 \%$ \\
Apnea & 17 & $31.48 \%$ \\
Pallor & 3 & $5.56 \%$ \\
\hline
\end{tabular}


According to $\mathrm{pHmetry}$ results [physiological reflux $(\mathrm{n}=30)$ and GERD $(n=15)]$, distribution of symptoms in 45 remained patients was showed in TABLE 3; where it were HR-BRUE episodes reported as having occurred during or right after feeding, cyanosis, vomiting, apnea, choking, pallor, hypertonia and hypotonia. Also, in the TABLE 3 it was shown the association between the pHmetry results with prematurity $(P$-value $=0.120)$, type of delivery (natural birth or caesarean birth $)(P$-value $=0.738)$ and birth weight $(P$-value $=0.023)$. Curiously, the group with GERD presented $9 / 15(60 \%)$ cases of low birth weight versus $7 / 30(23.33 \%)$ cases in the groups with physiological reflux (odds ratio - conditional maximum-likelihood estimate $(\mathrm{cMLE})=4.73 ; 95 \%$ confidence interval $=1.08$ to 23.11 ).

The $\mathrm{pHmetry}$ variables were compared between term and preterm patients. We found that number of reflux acid episodes lasting longer than 5 min was statistically significant $(P$-value $=0.028)$ being higher in the preterm individuals [preterm: $7.55 \pm 4.77$ events vs term: 4.90土4.13 (TABLE 4).
Finally, GERD diagnosed by pHmetry was not statistically related to gender $(P$-value $=0.757)$, age at first HR-BRUE episode $(P$ value $=0.960)$, and age at the time of the pHmetry $(P$-value $=0.720)$.

\section{DISCUSSION}

GERD diagnosed by prolonged esophageal pHmetry in HRBRUE infants occurred in one third of our patients. Frequency of GERD is closely related to the method used for its investigation. In 1991, a study in infants with a history of near-miss sudden infant death, used continuous esophageal $\mathrm{pH}$ monitoring and polygraphic recording in 49 infants showed pathologic gastroesophageal reflux in $34(69 \%)$ patients ${ }^{(17)}$, using the Boix-Ochoa parameters ${ }^{(18)}$. GERD investigated by the radioisotope milk scan method occurring in $26 \%$ of infants diagnosed with ALTE ${ }^{(1)}$ and $8 / 33(24 \%)$ in HR-BRUE, but there were no reports on the methods used to diagnose GERD ${ }^{(12)}$. A study conducted by Macchini et al. found $80 \%$ of patients with ALTE were diagnosed with GERD

TABLE 3. Distribution of clinical characteristics/symptoms and pHmetry results in infants with high-risk Brief Resolved Unexplained Event.

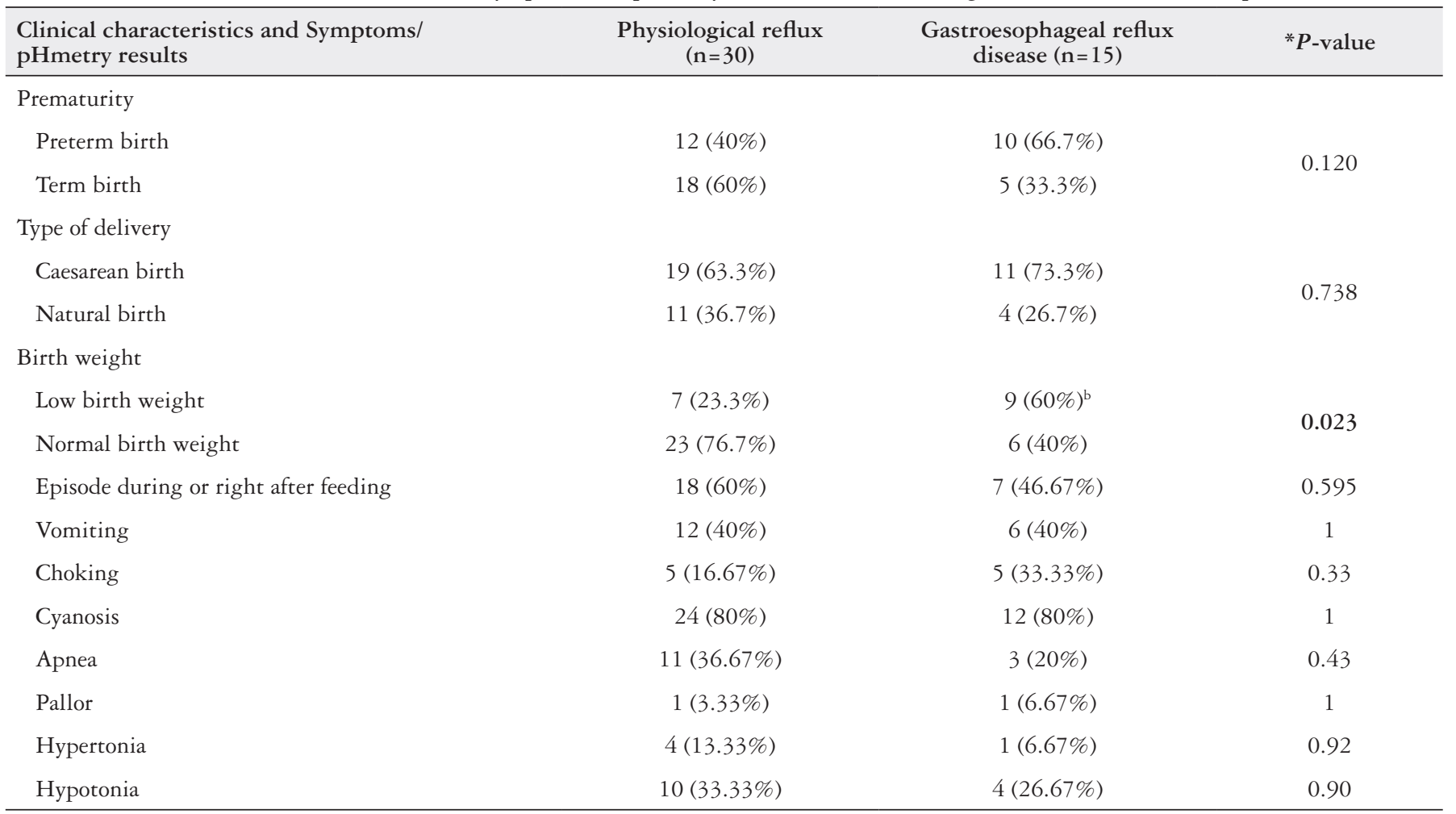

*Fisher's exact test. Positive $P$-value is shown as presented bold-type. Alpha: 0.05. 'ंOdds Ratio CMLE: 4.73 and $95 \%$ confidence interval: 1.078 to 23.11 . The odds ratio was calculated based on low birth weight in the group with gastroesophageal reflux.

TABLE 4. pHmetry variables compared between term and preterm infants with high-risk Brief Resolved Unexplained Event.

\begin{tabular}{|c|c|c|c|}
\hline pHmetry variables & Preterm & Term & ${ }^{*} P$-value \\
\hline Number of acid reflux episodes $($ mean \pm SD) & $42.30 \pm 22.34$ & $36.65 \pm 20.08$ & 0.289 \\
\hline Esophageal Clearance-min/refl $\left(\right.$ mean $\left._{ \pm} \mathrm{SD}\right)$ & $3.60 \pm 1.89$ & $2.72 \pm 1.21$ & 0.201 \\
\hline
\end{tabular}

${ }^{\#}$ Acid Reflux episodes: a decrease in $\mathrm{pH}$ below four that lasts for more than $10 \mathrm{sec}$. "Mann-Whitney Test. Positive $P$-value is shown as presented bold-type. Alpha: 0.05 . 
by pHmetry. The authors used RI: $<3 \%, 3-7 \%$, and $>7 \%$ and conclude that severity of GERD influenced on normalization of cardiorespiratory monitoring, suggesting that treat reflux could prevent recurrence of ALTE $^{(13)}$. However, pHmetry has reference values identified in healthy infants, being able to identify physiological reflux. The diagnosis of pathological reflux in children under 1 year of age was RI $>10 \%{ }^{(16)}$ in our study. We had used these criteria because our concern that diagnosis of GERD may lead to unnecessary treatment, and perhaps delay investigation of other disorders. BRUE episodes did not occur during pHmetry monitoring although $33 \%$ of those who reported having a HRBRUE demonstrated having GERD due to the 24-hour esophageal $\mathrm{pH}$ monitoring parameters.

MII-pH monitoring revealed acid or nonacid reflux in 2/3 of 53 HR-BRUE infants, non-acid reflux events were the most common findings $(66 \%)^{(19)}$. A study performed in 25 infants presenting with BRUE who underwent concurrent MII-pH and video-polysomnography showed severe esophageal acid exposure (RI>7\%) is associated with increased reflux-associated symptoms in wake state ${ }^{(20)}$.

The median age at which the patients presented the first symptoms was 36 days and the median age at which the pHmetry test was performed was 65 days. This delay of approximately one month possibly could be justified by a delay in referral to hospitals which have necessary resources for a complete investigation.

Despite not being related to gender, age at first HR-BRUE episode, age at the time of the pHmetry, prematurity or type of delivery; GERD was statistically related to low birth weight, as described in the literature ${ }^{(21)}$. Comparing pHmetry of preterm and term infants, we found higher number of longest acid reflux in preterm, compared to that of term infants, what was also found in a MII-pH monitoring study ${ }^{(19)}$.

It is known that pHmetry has some limitations for the diagnosis of GERD in infants and young children, because it is not sensitive to detect non-acid reflux ${ }^{(2,10)}$. Notably, $\mathrm{pH}-\mathrm{MII}$ is not available in health care units in resource-limited countries and a recent consensus published by NASPGHAN and ESPGHAN recommend both methods for properly investigation of GERD ${ }^{(10)}$.

The symptoms reported as HR-BRUE occurred during or right after feeding in half of infants, and there was no symptom significantly involved in HR-BRUE and GERD. A recent systematic review demonstrates that the reported prevalence of GERD symptoms may vary considerably in infants and children ${ }^{(22)}$. Given this outcome, it was not possible to select clinical history that could assist in selecting patients who would be more likely to have GERD.

Weir et al. (2009) reported that neither the clinical history nor observed feeding sessions can accurately predict which patients have oropharyngeal dysphagia versus GERD ${ }^{(23)}$. During the neonatal period, a proven relation occurs through such symptoms and the triggering of laryngeal reflex caused by stimulus of laryngeal chemoreceptors, promoting glottal closure or spasm as a protective reflex of the airways, preventing any foreign body from entering the lower respiratory system ${ }^{(24-27)}$. Considering that caregivers had reported symptoms of BRUE as occurring during or right after feeding in half of the studied infants, we reinforce the importance of investigating and treating appropriately aerodigestive dysfunctions in the management of BRUE ${ }^{(28)}$.

Although GERD is one of the most remembered etiologies of BRUE by caregivers and physicians, American Academy of Pediatrics recommends that evaluation of a baby after BRUE is driven by a complete clinical history and a careful physical examination. In most cases, the child is free of symptoms at the time the medical evaluation takes place, allowing a systematic approach to anamnesis and physical examination. The complementary tests that should be evaluated in a child after an episode of BRUE include venous blood gases, toxicological studies, bacterial or viral cultures, electroencephalogram, pHmetry or MII-pH monitoring, neuroimaging, and other features ${ }^{(2)}$.

As a limitation of our study, we were not able to change the formula to extensive hydrolyzed formula or $100 \%$ amino-acid formula after GERD diagnosis, because GERD guideline from NASPGHAN 2018 was published after the cases had been included in our study. Nowadays, infants suspected of having GERD are systematically tested for allergic etiology using hypoallergenic formula in our clinics ${ }^{(10)}$.

\section{CONCLUSION}

GERD and life-threatening events relation is still controversial, since reflux assessment methods vary widely. GERD diagnosed by pHmetry was found in 33\% of infants who presented HR-BRUE. The symptoms reported as HR-BRUE occurred during or right after feeding in half of infants, and there was no symptom significantly involved in HR-BRUE and GERD. Future studies are needed to understand the role of GERD in BRUE etiopathogenesis. Curiously, this is the first report from Brazil that associate the BRUE or ALTE with esophageal $\mathrm{pHmetry}$ or $\mathrm{pH}-\mathrm{MII}$ in infants or preterm.

\section{Authors' contribution}

Bellomo-Brandão MA: conceived the project, collected participants' data, wrote and critically reviewed the study. Stranguetti FM: validated the results. Peixoto AO: accounted for supervision, performance and validation using reproducibility criteria. Stranguetti FM, Lopes IF, Lomazi EA, Peixoto AO: evaluated medical records of the study participants and validated findings using reproducibility criteria. Marson FAL: analyzed an interpreted the data. All authors have read and approved the last version of the manuscript prior to submission.

\section{Orcid}

Maria Angela Bellomo-Brandão: 0000-0002-1145-2606.

Fernanda Maso Stranguetti: 0000-0002-2975-8187.

Iara Ferreira Lopes: 0000-0001-8810-5218.

Andressa Oliveira Peixoto: 0000-0002-8407-4087.

Fernando Augusto Lima Marson: 0000-0003-4955-4234.

Elizete Aparecida Lomazi: 0000-0001-5504-4746. 
Bellomo-Brandão MA, Stranguetti FM, Lopes IF, Peixoto AO, Marson FAL, Lomazi EA. Doença do refluxo gastroesofágico em lactentes que apresentaram Eventos Resolvidos Breves Não Explicados - Brief Resolved Unexplained Event (BRUE). Arq Gastroenterol. 2021;58(4):424-8.

RESUMO - Contexto - O termo Eventos Resolvidos Breves Não Explicados (Brief Resolved Unexplained Event - BRUE) é uma descrição do evento agudo que ocorre em lactentes menores de 1 ano de idade que inclui pelo menos uma das seguintes características: cianose ou palidez; respiração ausente, diminuída ou irregular, alteração acentuada no tônus ou nível alterado de responsividade. É necessário um procedimento investigativo para identificar o fenômeno desencadeante naqueles que apresentam alto risco de complicações. A pHmetria esofágica prolongada tem sido usada como uma ferramenta na pesquisa de doença do refluxo gastroesofágico (DRGE) como uma das etiologias subjacentes. Objetivo - Este estudo tem como objetivo verificar a frequência da DRGE em lactentes de até 1 ano de idade, quando a pHmetria foi realizada para investigação da BRUE de alto risco, e analisar se alguma característica clínica ou sintoma particular relatado pelos cuidadores durante a BRUE poderia estar correlacionado a DRGE. Métodos - Foi realizado um estudo observacional, transversal, cujos dados foram coletados retrospectivamente de pacientes menores de 1 ano de idade, que realizaram pHmetria em hospital terciário para investigação de BRUE de alto risco de outubro de 2008 e janeiro de 2018. Para a análise dos prontuários, um protocolo de coleta de dados incluiu: sexo, idade no primeiro episódio de BRUE de alto risco, idade no momento da pHmetria, idade gestacional, tipo de parto (normal ou cesárea), peso ao nascer e sintomas associados a alto risco-BRUE relatado por cuidadores. A relação entre as variáveis foi avaliada por meio do teste exato de Fisher, qui-quadrado e teste de Mann-Whitney. O nível de significância foi estabelecido em 0,05. Resultados - Foram incluídos 54 lactentes (pré-termo 25, termo 29), 62,9\% do sexo masculino, idade mediana na BRUE de alto risco foi de 36 dias. De acordo com o relatório do cuidador, $53,7 \%$ dos episódios de BRUE de alto risco ocorreram durante ou logo após a alimentação. Resultados da pHmetria: nove resultados da pHmetria foram considerados inconclusivos, refluxo fisiológico $(n=30)$ e DRGE $(n=15)$. A frequência de DRGE diagnosticada por pHmetria foi de $33 \%$. A DRGE não foi estatisticamente relacionada ao sexo $(P=0,757)$, idade no primeiro episódio de BRUE de alto risco $(P=0,96)$, idade no momento da pHmetria $(P=0,72)$ prematuridade $(P=0,321)$ ou tipo de parto $(P=0,738)$. A DRGE foi estatisticamente relacionada ao baixo peso ao nascer $(P=0,023)$. Não houve associação entre os sintomas relatados pelos cuidadores durante BRUE de alto risco e o diagnóstico de DRGE. Conclusão - A DRGE diagnosticada pela pHmetria foi encontrada em um terço dos lactentes que vivenciaram BRUE de alto risco, mostrando a importância da investigação adequada. Em metade das crianças, o evento ocorreu durante ou logo após a alimentação. Além do baixo peso ao nascer, não foi possível selecionar outros dados da história clínica que sugiram que esses pacientes terão maior probabilidade de apresentar DRGE.

Palavras-chave - Eventos inexplicáveis breves e resolvidos; eventos de aparente risco de vida; doença do refluxo gastroesofágico; lactentes; neonatos.

\section{REFERENCES}

1. American Academy of Pediatrics. National Institutes of Health Consensus Development Conference on Infantile Apnea and Home Monitoring. Pediatrics. 1987;79:292-9.

2. Tieder JS, Bonkowsky JL, Etzel RA, Franklin WH, Gremse DA, Herman B, et al. Clinical practice guideline: brief resolved unexplained events (formerly apparent life-threatening events) and evaluation of lower-risk infants: executive summary. Pediatrics. 2016;137:e20160591.

3. Tate C, Sunley R. Brief resolved unexplained events (formerly apparent life-threatening events) and evaluation of lower-risk infants. Arch Dis Child Educ Pract Ed. 2018;103:95-8.

4. McFarlin A. What to do when babies turn blue: beyond the basic brief resolved unexplained event. Emerg Med Clin North Am. 2018;36:335-47.

5. Gatto A, Paglietti MG, Bocchi MB, Lazzareschi I, Cutrera R, Valentini P. Brief resolved unexplained events and apparent life-threatening events: the wall between guidelines and clinical practice. Acta Paediatr. 2020;109:1267-68

6. Baird DC, Harker DJ, Karmes AS. Diagnosis and treatment of gastroesophageal reflux in infants and children. Am Fam Physician. 2015;92:705-14.

7. Barfield E, Parker MW. Management of pediatric gastroesophageal reflux disease. JAMA Pediatr. 2019;173:485-6.

8. Colletti RB, Di Lorenzo C. Overview of pediatric gastroesophageal reflux disease and proton pump inhibitor therapy. J Pediatr Gastroenterol Nutr. 2003;37:S7-s11.

9. Czinn SJ, Blanchard S. Gastroesophageal reflux disease in neonates and infants: when and how to treat. Paediatr Drugs. 2013;15:19-27.

10. Rosen R, Vandenplas Y, Singendonk M, Cabana M, DiLorenzo C, Gottrand F, et al. Pediatric Gastroesophageal Reflux Clinical Practice Guidelines: Joint Recommendations of the North American Society for Pediatric Gastroenterology, Hepatology, and Nutrition and the European Society for Pediatric Gastroenterology, Hepatology, and Nutrition. J Pediatr Gastroenterol Nutr. 2018;66:516-54.

11. Davies F, Gupta R. Apparent life threatening events in infants presenting to an emergency department. Emerg Med J. 2002;19:11-6.

12. Colombo M, Katz ES, Bosco A, Melzi ML, Nosetti L. Brief resolved unexplained events: Retrospective validation of diagnostic criteria and risk stratification. Pediatr Pulmonol. 2019;54:61-5.

13. Macchini F, Morandi A, Cognizzoli P, Farris G, Gentilino V, Zanini A, et al. Acid gastroesophageal reflux disease and apparent life-threatening events: simultaneous pH-metry and cardiorespiratory monitoring. Pediatr Neonatol. 2017;58:43-7.

14. World Health Organization (WHO). [Internet]. Available from: www.who.int/ news-room/fact-sheets/detail/preterm-birth
15. World Health Organization (WHO). Newborns with low birth weight (\%). [Internet]. Available from: https://www.who.int/whosis/whostat2006NewbornsLowBirthWeight.pdf

16. Vandenplas Y, Sacré-Smits L. Continuous 24-hour esophageal $\mathrm{pH}$ monitoring in 285 asymptomatic infants 0-15 months old. J Pediatr Gastroenterol Nutr. 1987;6:220-4

17. Veereman-Wauters G, Bochner A, Van Caillie-Bertrand M. Gastroesophageal reflux in infants with a history of near-miss sudden infant death. J Pediatr Gastroenterol Nutr. 1991;12:319-23.

18. Boix-Ochoa J, Lafuenta JM, Gil-Vernet JM. Twenty-four-hour exophageal pH monitoring in gastroesophageal reflux. J Pediatr Surg. 1980;15:74-8.

19. Jarasvaraparn C, Belen Rojas Gallego M, Wang B, Crissinger KD, Gremse DA. The Characteristics of Esophageal Multichannel Intraluminal Impedance-PH Measurements in Infants Experiencing Brief Resolved Unexplained Events. Ann Gastroenterol Dig Disord. 2018;1:1-8.

20. Sankaran J, Qureshi AH, Woodley F. Effect of Severity of Esophageal Acidification on Sleep vs Wake Periods in Infants Presenting with Brief Resolved Unexplained Events. J Pediatr. 2016,179:42-8.

21. Dutta S, Singh B, Chessell L, Wilson J, Janes M, McDonald K, et al. Guidelines for feeding very low birth weight infants. Nutrients. 20158;7:423-42.

22. Singendonk M, Goudswaard E, Langendam M, van Wijk M, van Etten-Jamaludin F, Benninga $\mathrm{M}$, et al. Prevalence of gastroesophageal reflux disease symptoms in infants and children: a systematic review. J Pediatr Gastroenterol Nutr. 2019;68:811-7.

23. Weir K, McMahon S, Barry L, Masters IB, Chang AB. Clinical signs and symptoms of oropharyngeal aspiration and dysphagia in children. Eur Respir J. 2009;33:604-11.

24. Bauman NM, Sandler AD, Schmidt C, Maher JW, Smith RJ. Reflex laryngospasm induced by stimulation of distal esophageal afferents. Laryngoscope. 1994;104:209-14.

25. Thach BT. Reflux associated apnea in infants: evidence for a laryngeal chemoreflex. Am J Med. 1997;103:120s-4s.

26. Hernández-Cortez E. Old laryngospasm complication: new treatments. Anest. Méx. 2017;8:00327.

27. Jadcherla SR. Pathophysiology of aerodigestive pulmonary disorders in the neonate. Clin Perinatol. 2012;39:639-54.

28. Duncan DR, Amirault J, Mitchell PD, Larson K, Rosen RL. Oropharyngeal dysphagia is strongly correlated with apparent life-threatening events. J Pediatr Gastroenterol Nutr. 2017;65:168-72. 